\title{
The Linguistic Landscape of Kampung Bahari Presenting the Coastal Community Development of Tambak Lorok Semarang
}

\author{
Deli Nirmala ${ }^{1, *}$ \\ ${ }^{1}$ Department of Linguistics, Faculty of Humanities, Diponegoro University, Semarang - Indonesia
}

\begin{abstract}
Kampung Bahari Tambak Lorok Semarang being prepared for a new potential tourism destination is changing not only in its infrastructure but also its social behavior. The changing infrastructure changes social structure, social belief, and social identity. The changes may be integrated in many aspects like environment, literacy, education, and economy. This paper aims at discovering the linguistic landscape which promotes the coastal community development of Kampung Bahari to create Kampung Bahari to be a nicer place to live and to visit. It seems that waste is an important problem in Tambak Lorok in order that this can make Kampung Bahari clean and be visited by many domestic or foreign tourists. The public signs indicating the facilities including waste management of the coastal community at Kampung Bahari were captured and analyzed using abductive inferential method. The result shows that the linguistic landscape of the development of Kampung Bahari indicates that Kampung Bahari has infrastructure which shows social awareness on environment, provides the community needs in economy, health, and literacy. The needs can be identified through the public names like Taman Baca Seroja indicating literacy activities, Koperasi Simpan Pinjam for banking system, Masjid Sholaha for spiritual needs. Komunitas Camar Peduli Lingkungan indicates environmental awareness and care. This study gives contribution to linguistic landscape study in terms of the contribution of linguistic study to regional development issues.
\end{abstract}

Keywords: Kampung Bahari; linguistic landscape; waste; literacy; Tambak Lorok Semarang

\section{Introduction}

Linguistic landscape can be used for representing social, cultural, environmental, and typological conditions of the cities or parts of the cities through the language used in public signs, place-names, billboards, banners, for instance. It has been a recent study with fast development by many researchers with different focuses. Most of the researchers have studied linguistic landscape of the cities in order that they can capture the social development or movement, ideology, and identity. Leeman and Modan [1] investigated linguistic landscape of the city from commercial point of view, Malinowski [2] elaborated the linguistic landscape of the cities in Korea from virtual text on google shot. Blackwood and Tufi [3] study the linguistic landscape of the cities of Mediterranean, which can identify and explore some aspects of coastal cities. Monie [4] studies the linguistic landscape of the protests in Manila. The linguistic landscape study focusing on the English usage in the cities was done by [5] investigating the linguistic landscape of English usage in Sozhou especially in presenting the transgressive practices of English in order to show the ethnolinguistic vitality of the Chinese city, Sozhou. Similar to [5], Lanza and Woldermariam [6] study the linguistic landscape of Addis Ababa. Lanza and Woldermariam [6] studied how globalization era has influenced Addis Ababa in showing its identity represented by the use of English in public names and brands. Regarding to multilingual phenomena, Gorter [7], Hurt [8], and Mezgec [9] study the linguistic landscape in multilingual contexts. Mezgec [9] studies the Slovene minority languages in multilingual contexts marking identity. The linguistic landscape studies of cities indicating multilingualism can be applied for language teaching.

Gorter [10] reviewed the development of the linguistic landscape study in different focuses and methodologies. Gorter [10] can show definitions, perspectives, and methodologies. According to [11], studying linguistic landscape is not merely dealing with linguistics but also semiotics indexing social identity and movement. Besides linguistic landscape belongs to sociolinguistics, it corresponds to other disciplines like semiotics, discourse analysis, pragmatics, cognitive linguistics, and applied linguistics. This depends on the perspective the researchers have. In this current study, the researcher tries to study the linguistic landscape of Kampung Bahari of Tambak Lorok Semarang in order to capture the coastal development arranged by the government from pragmatic and cognitive-linguistic points of view.

From the linguistic landscape, the development of Tambak Lorok in terms of social and environmental phenomena can be explored. The exploration can be 
done using presupposition triggers proposed by [12]. According to [12], presuppositions can be identified from their triggers i.e. the expressions that lead to what the speaker presupposes. The use of proper nouns and definite article are the examples of existential presuppositions which indicate that something exists. Therefore, public names, based on presupposition theory, can be classified as the expressions containing existential presuppositions.

Cognitive linguistics proposed by [13] is the basis of understanding how mental space is constructed in the mind. Public names convey the names of the space which is stored in the mind as mental lexicon. The mental lexicon gives a picture of the spaces referred to. This theory supports the ideas proposed by [14] proposing mental space represented by mental lexicon. Fauconnier [14] stated that the world is considered as a container. People live in the world as a container. What is in language may construct mental spaces based on base, viewpoint, and focus. Regarding the public names, society uses names for marking the spaces in the world for constructing the spaces in the mind.

\section{Method}

The public names in the public signs found in Kampung Bahari Tambak Lorok were purposively taken from only the signs found in Kampung Bahari Tambak Lorok Semarang. They were collected using non-participant observation and documented as album through camera. The public names and signs including store names or signs were analyzed using referential, orthographical, and abductive inferential methods. The referential was used to uncover the meaning or referent of the signs, while the orthographic identity method was used to dig up the additional meaning of the words used in the public space. The use of orthographic devices like bold, italic, capital letters were also analyzed. The abductive inferential method was used to infer the content of the use of the public signs, to connect one phenomenon to another represented in different signs in order to synthesize the ideas constructed from different sources. The idea constructed was used to show the community development represented in the public signs used in Kampung Bahari. What is happening in the community reflected in the public signs and names can represent the role of the community and the government in developing Kampung Bahari. The other method used was translational identity method. It was used to translate the public's names, for example, from Bahasa Indonesia into English in order that the writer can explain the reference of the names.

\section{Results and Discussion}

The coastal development represented in the linguistic landscape of Kampung Bahari indicates some issues related to names of the public places, infrastructures, literacies, and environmental awareness, and services offered by the people living in Kampung Bahari. From the public names or signs, the local identities can be presented. The result of the study will be presented based on space orientation from the front side to the backside leading to Java Sea shoreline.

Kampung Bahari is a new name for Tambak Lorok fisherman area in Semarang, Indonesia which was previously very slum but was designed as the area which has new prospects and performance. The public sign of Kampung Bahari can be seen in the entrance of the area. When visitors enter the area, they will know that the area is called Kampung Bahari. In other words, the public name gives the picture of what kind of place it is. Kampung is an area and Bahari is marines in Bahasa Indonesia. It the area which has specific characteristics referring to fisheries, buying and selling marine products like fish, crab, shrimp, and shell.

The development can be seen from the public name built in the entrance of Kampung Bahari. This can be seen from the name "Kampung Bahari". From presupposition triggers, i.e. name, it can be inferred that Kampung Bahari as a place that exists. In the picture, we can read Kampung Bahari, the name of the area. Entering the area, we can see the names of the shops, food stall, and the services offered. On the left side of the street is the market, Pasar Tambak Lorok, the new facility built in Tambak Lorok.

\subsection{Name}

From the name "Bahari", it implies that Tambak Lorok now is not only the place of fishermen who make a living in the area, but it is more than that. It is designed not only for the fishermen but also for the public. By using the word "Bahari", Tambak Lorok provides services for enjoyment that is tourism, meaning that not only Tambak Lorok people who enjoy the place but also other people coming in the area. The name "Kampung Bahari" invites people to be inquisitive about the content of the area, the activities, and the facilities offered to the public. The name invites the visitors to enjoy the sites or spots which are interesting for them dealing with marine living. The following is the public name of Kampung Bahari. 


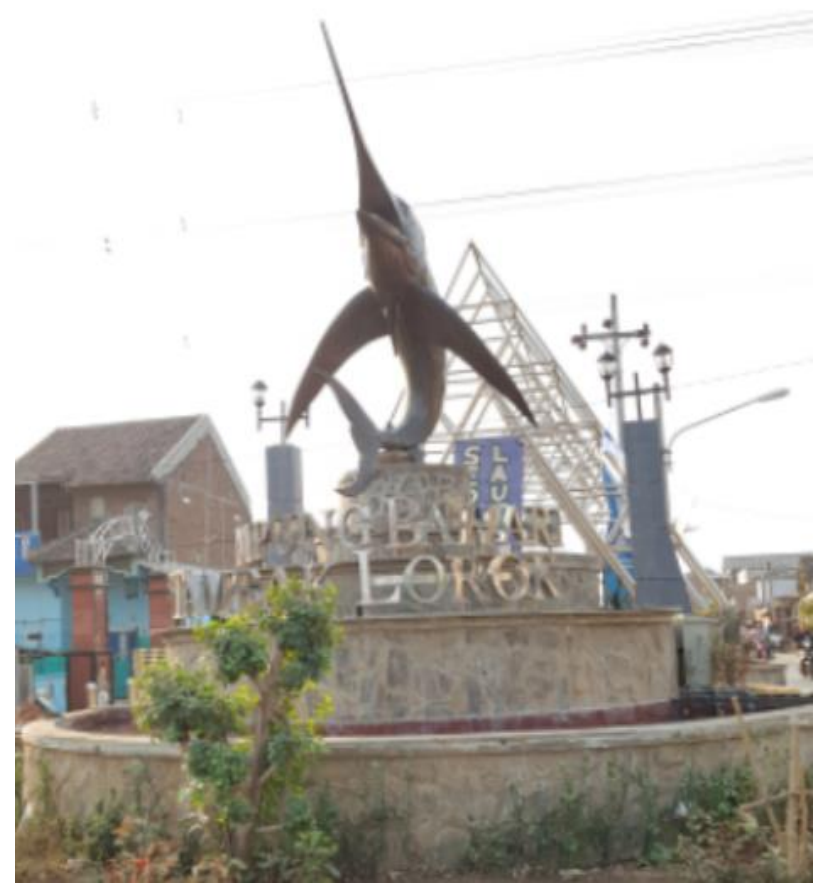

Fig. 1. Public Name "Kampung Bahari" of the entrance gate

\subsection{Infrastructure}

The prominent infrastructure in Kampung Bahari is the existence of "Pasar Tambak Lorok", "Masjid Sholaha", "Koperasi Simpan Pinjam Syariah". The word "pasar" meaning market, indicates a place for buying and selling. In the market, the most dominant goods sold is fish with its kind, whether it is fresh, smoked, or salty fish.

The expression "Pasar Tambak Lorok" indicates the existence of the market provided by the government to give a facility for the people living in Tambak Lorok or visitors coming for buying or selling their needs especially fish. The expression "Pasar Tambak Lorok" indicating the place for specific activity --- buying and selling have been provided in Tambak Lorok recently. It was not established before Kampung Bahari. The domain implies the use of specific genre, i.e. buying and selling conversations including bargaining, rejecting, and accepting. It also implies a specific pattern of interaction different from other types of genre.

Another public facility provided at Tambak Lorok or Kampung Bahari is Masjid Sholaha as the public name of the mosque in Tambak Lorok. The name indicates a public place for praying especially Islam followers. Masjid Sholaha is one of the biggest mosques in Tambak Lorok. From the name, people understand that this is the place for praying for special group that is Islam. This building is exclusively used by moslem. It indicates the routines the moslem does daily, weekly, and yearly. The public name implies that the building is used for special purposes, that is religious activities. The name also implies that only moslem who use the building. If they are dominantly found in Tambak Lorok, it can be inferred that most of people in Tambak Lorok are Islam followers.
Another building provided is "Klinik" or medical clinic. This service is considered important provided for the people living in Tambak Lorok. The public sign implies that there are people or group of people running their business in giving health service and there are people who need the service. This is a kind of mutual benefit service. This business involves some professions like doctors, nurses and other paramedics, administrators, drivers, cleaning services, and the managers or owners of the clinic organizing the clinic. There must be a management team handling the system of the clinic in planning, organizing, actuating, and controlling the system.

Entering the clinic, there is an organizational structure describing roles and relationships among the components of the structure. Who and what relationship they have can be conveyed by the structure. The structure is the linguistic landscape of the limited area of the clinic.

\subsection{Literacy}

Literacy becomes a concern in Tambak Lorok. There is a facility for the people living there. From the public name, there are two activities run in Tambak Lorok, i.e. PAUD or early child education or kindergarten and Taman Baca or reading corner.

The public name "PAUD" indicates a place for educating early children. This implies that Tambak Lorok people have early child education system run by the society. It is an informal institution provided by PKK or women's organizations under village authority. The place gives opportunities for early children to get education in their neighbourhood.

Besides education, literacy becomes a concern. There are two public places for developing literacy in Tambak Lorok, namely Seroja and Teratai. They are run by the community organized by ASA EDU. ASA EDU is organized by university students from UNDIP and UNNES, for example.

\subsection{Environmental awareness}

Environmental awareness is shown by the public signs that we can see on the trash can in every five hundred meters of the main street in order that everyone who is passing the street and wants to throw out the garbage, they can put it into the can. The following is the picture indicating where the sign is displayed.

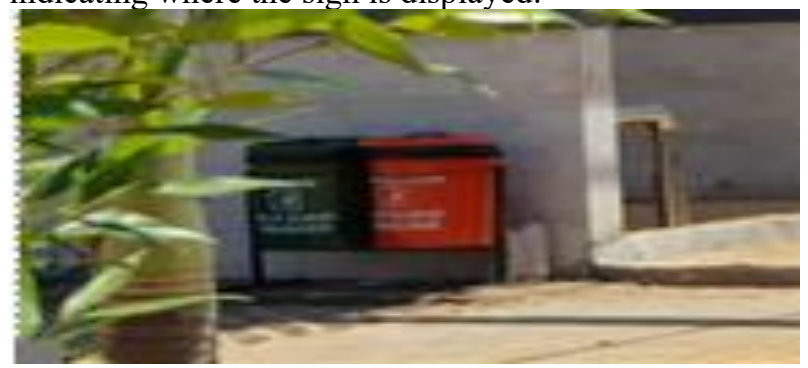

Fig. 2. Public Sign "Sampah Organik / Non-Organik" 
The sign "Sampah Organik / Non-Organik". The sign can be found in the trash containers placed on the ground next to the wall. The twin containers are placed along the road of Kampung Bahari, which is currently renovated. From the sign, the trash is classified as organic and nonorganic garbage. The classification may imply that if someone wants to put the garbage in the can, s/he must pay attention to the letters written on the can. If $s /$ he wants to put the organic garbage, $s /$ he must throw it into the organic can, but if $\mathrm{s} /$ he has non-organic one, $\mathrm{s} /$ he should throw it to the non-organic one. The different signs will also give implication to the garbage collectors. They will treat the garbage in different ways. They will use the organic one for making fertilizers and use the non-organic garbage for many uses depending on the materials for recycling or reusing.

The statements "organic" and "non-organic garbage" implies attitudes, disciplines, awareness, and actions regarding to the process of the garbage treatment which can help the natural renewability of the region. The attitudes can be categorized as positive and negative ones. If they have positive attitude they will follow what the statements imply that everybody is required to put the garbage depending on the classification. The "organic statement" implies that they should put the organic garbage into the garbage container. It can be inferred from the sign that if people know the container and put the garbage suitable to the container, they have positive attitudes.

Dealing with environment, there is a public sign Komunitas Camar Peduli Lingkungan. The sign indicates the activities of the community concerned with environment. The sign implies the existence of environmental awareness by the community.

Regarding the environment, there is a mobile sign which can be found in the vehicle used for transporting the garbage. The Ministry of Environment gives support to the society by giving them garbage carriers.

From the signs, it can be inferred that environment becomes the responsibility of both the society and the government. The government provides some vehicles which are placed in the garbage pooling area. This helps the garbage collectors put it properly.

\subsection{Services}

One of the services is medical service. There is a public name "Klinik" or medical clinic. The public sign indicates that the society can use the service provided by clinic owner maybe governmental or non-governmental agencies. This implies that the society concerns with health as a primary need.

Another service is cooperation or a small syariah banking system name Koperasi Simpan Pinjam dan Pembiayaan Syariah.

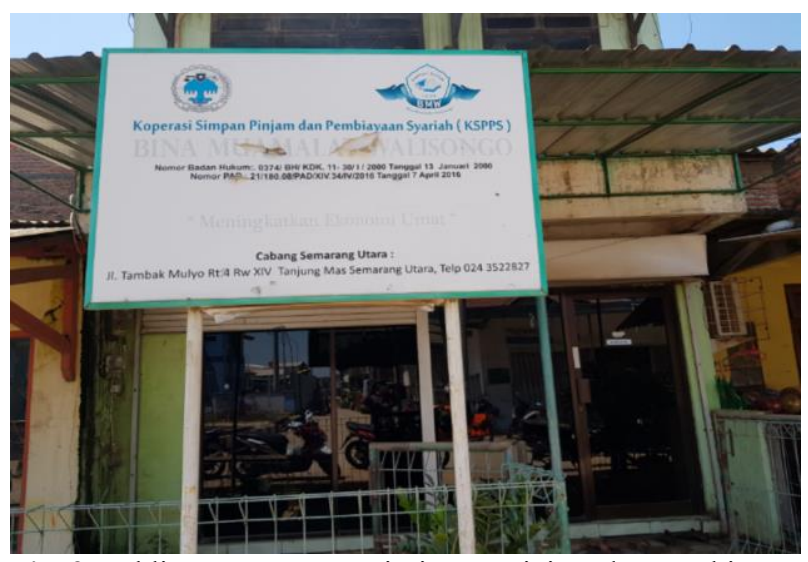

Fig. 3. Public name "Koperasi Simpan Pinjam dan Pembiayaan Syariah"

The Public name "Koperasi Simpan Pinjam dan Pembiayaan Syariah" indicates that in Kampung Bahari there is a service called koperasi or cooperation for saving and credit and other purposes as moslem friendly. The word "syariah" implies Islamic law. It implies that the cooperation run based on Islamic principles.

The public sign may be inferred that the management team of the cooperation is inviting moslem people to invest their money to the cooperation since it is using or applying Islamic banking system which avoids riba. Riba is a system that gives interests to the client. This kind of practice is not allowed to being applied by moslem people. It is restricted.

From the public sign, it can be inferred that the society is dominantly moslem people. If there are no moslems living in the area, there is a question to whom the cooperation is for.

From multilingualism perspective, this study cannot present the result from multilingualism perspective. There is a foreign language used in the public names or signs namely Arabic that can be identified from the word syariah. Syariah means Islamic law. From the word, it can be inferred that the banking system used is Islamic one.

Other services that can be found in Kampung Bahari among other things are Tambal Ban or Filling Flat Tyre. The public sign informs the passer-by that there is a service for fixing the flat tyre. If you have flat tyre, you can have it filled or fixed.

There are shops that can fulfil the people's basic needs of food. The shops inform what they are selling. The public names invite people to buy their goods sold. There are some public names for food stall or warung makan.

The study can contribute to both sides namely Tambak Lorok people and the people from different areas both domestic and overseas. On the one hand, the study can give advantages to society since they have shown their improvement which can attract people to visit their area which can give more economic benefits because they can buy marine products or services offered by the local people. Popularity can give a lot of benefits. On the other hand, the people outside Tambak Lorok or other countries can get information related to new tourism objects which can give them alternatives for 
refreshing. Since the paper is published online which can reach people in different globes.

\section{Conclusion}

From the analysis, it can be concluded that from linguistic landscape people can provide complete information related to the city or place in order that they can make planning, developing, or finding some policies that can support each other.

The linguistic landscape of Kampung Bahari gives a picture of the potential condition of the area as Kampung Bahari which may be a new tourism destination in Semarang. It provides the people's needs in all aspects of life namely economy, health, environment, transportation, and even clothes.

This study can support the other studies in linguistic landscape in depicting a portrait of a part of the coastal development in Pantura, Indonesia.

In this occasion, I would like to express my gratitude to the Dean of the Faculty of Humanities, Diponegoro University for the grant of the research.

\section{References}

1. J. Leeman and G. Modan, Selling the City: Language, Ethnicity, and Commodified Space, Linguistic Landscape in the City, Elana Shohamy, Eliezer Ben-Rafael, and Monica Barni. Clavedon: Multilingual Matters Ltd. (2010).

2. D. Malinowski, Showing seeing in the Korean, Linguistic Landscape in the City. Elana Shohamy, Eliezer Ben-Rafael, and Monica Barni. Clavedon: Multilingual Matters Ltd. (2010)

3. R. J. Blackwood and S. Tufi. The Linguistic Landscape of the Mediterranean: French and Italian coastal cities. London: Palgrave Macmillan. (2015)

4. J. Monje, Hindi Bayani/Not a Hero: The Linguistic Landscape of Protest in Manila, Social Inclusion (ISSN: 2183-2803), 5, 4: 14-28 (2017)

5. S. Li. English in the Linguistic Landscape of Sozhou: creative, fluid and transgressive English practices in a Chinese city, English Today, 31, 1: 27-33 (2015)

6. E. Lanza and H. Woldemariam, Indexing modernity: English and branding in the linguistic landscape of Addis Ababa, International Journal of Bilingualism, 18(5): 491 - 506 (2014)

7. D. Gorter, Linguistic Landscape: A New Approach to Multilingualism, Clavedon: Multilingual Matters ltd. (2006) http://www.multilingual-matters.com

8. F. M. Hult, Drive-thru linguistic landscaping: Constructing a linguistically dominant place in a bilingual space, International Journal of Bilingualism, 18(5): 507-523 (2014)

9. M. Mezgec, Linguistic Landscape as a Mirror: the Case of the Slovene Minority in Italy, Journal of Ethnic Studies, 77: 67-86 (2016)
10. D. Gorter, Linguistic Landscapes in a Multilingual World, Annual Review of Applied Linguistics, 33: 190-212 (2013)

11. M. Moriarty, Languages in motion: Multilingualism and mobility in the linguistic landscape, International Journal of Bilingualism, 18(5): 457-463 (2014)

12. G. Yule, Pragmatics, Oxford: Oxford University Press. (1996)

13. V. Evans and M. Green, Cognitive Linguistics: An Introduction, Edinburgh : Edinburgh University Press. (2006)

14. G. Fauconnier, Mappings in Thought and Language (1997). 